\title{
The European People's Party and the Amsterdam Treaty
}

\author{
Karl Magnus JOHANSSON
}

Alongside the intergovernmental or inter-state level and structures there are the transnational structures of, for example, political parties and their networks across state boundaries. They too have a role to play, directly or indirectly, in EU politics and, more specifically, in the politics of EU treaty reform. ${ }^{1}$

In recent years, there has been a resurgence of interest in 'political parties at the European level', as referred to treaty-wise from the Maastricht treaty onward, socalled Europarties. ${ }^{2}$ What explains this resurgence? One answer is that they have proved useful and play a role in EU politics. But despite this and their organizational development, Europarties remain under-researched and underestimated. Europarties, which are 'parties of parties' consisting of national member parties, are still insufficiently understood.

In this article, I look upon one of these Europarties, the centre-right and federalist European People's Party (EPP), and examine its activities and mobilization in order to influence the course and outcome of the negotiations leading to the adoption in

1. The origins of this article go back quite some years. It is the product of research originally conducted within my post-doctoral research project 'Transnational Party Networks and the Agenda of the European Union', based at the Swedish Institute of International Affairs, Stockholm, from September 1997 to June 2000. I gratefully acknowledge this funding. The project resulted mainly in three journal articles: K.M. JOHANSSON, Tracing the Employment Title in the Amsterdam Treaty: Uncovering Transnational Coalitions, in: Journal of European Public Policy, 1(1999), pp.85-101; K.M. JOHANSSON, Another Road to Maastricht: The Christian Democrat Coalition and the Quest for European Union, in: Journal of Common Market Studies, 5(2002a), pp.871-893; K.M. JOHANSSON, Party Elites in Multilevel Europe: The Christian Democrats and the Single European Act, in: Party Politics, 4(2002b), pp.423-439. The Centre for European Integration Studies in Bonn also provided financial and infrastructural support. My sincere thanks also go to all the people who were willing to be interviewed, for generously sharing their time and insights. For helpful comments and suggestions, I wish to thank Anne Deighton, the editors of this journal and the anonymous reviewers.

2. E. KÜLAHCI, Europarties: Agenda-Setter or Agenda-Follower? Social democracy and the disincentives for tax harmonization, in: Journal of Common Market Studies, 5(2010), pp.1283-1306; Special Issue: Transnationale Parteienkooperation in Europa: Empirische Grundlagen und konzeptionelle Perspektiven, in: Mitteilungsblatt des Instituts für soziale Bewegungen, 2(2011); S. VAN HECKE, Do Transnational Party Federations Matter? (... and Why Should We Care?), in: Journal of Contemporary European Research, 3(2010), pp.395-411; S. VAN HECKE, Polity-Building in the Constitutional Convention: Transnational Party Groups in European Union Institutional Reform, in: Journal of Common Market Studies, 5(2012), pp.837-852; T. POGUNTKE, M. MORLOK, H. MERTEN (eds), Auf dem Weg zu einer europäischen Parteiendemokratie, Nomos, Baden-Baden, 2013; E. STETTER, K. DUFFEK, A. SKRZYPEK (eds), In the Name of Political Union - Europarties on the Rise, FEPS, Brussels, 2013; Special Issue: Europarties between 'deepening' and 'widening', in: Acta Politica, 1(2014). 
1997 of what was to become the Treaty of Amsterdam (hereinafter ToA). ${ }^{3}$ The Intergovernmental Conference (IGC) presented an opportunity for the EPP to make a difference and to shape the $\mathrm{EU}$ in a federalist direction.

For reasons of space, the article does not cover in detail the content of the new treaty or the positions of individual member states and preference-formation at the domestic level. Instead, the focus is on the informal and the formal relationship between the treaty making process, the EPP and its party networks. The article deals with the informal ties among and between governmental and nongovernmental elites, including here the transnational organization of the EPP. There is the interplay between formal and informal politics. ${ }^{4}$ Informal integration covers political movements and long-standing flows and exchanges between actors such as ideological movements. ${ }^{5}$ Such movements organize themselves in the form of transnational networks; for instance European Christian Democracy, which in this way has played a significant role in and for European regional integration. ${ }^{6}$

3. In view of the first direct European elections, the EPP was founded in 1976 as an extra-parliamentary organization outside the European Parliament (EP), and emerged from the Christian Democratic parliamentary group, originally founded in 1953. In 1997, the EPP had 24 member parties and five heads of government-in Belgium, Germany, Italy, Luxembourg and Spain - and was also represented in the coalition governments of Austria and Finland, and of France before the change of government there in early June. It also bears noting that the EPP during the course of the 1990s underwent a difficult internal process of 'deepening' versus 'widening' with the challenge of incorporating (liberal-) conservative parties in its ranks.

4. W. WALLACE, The Transformation of Western Europe, Royal Institute of International Affairs and Pinter Publishers, London, 1990; K. MIDDLEMAS, Orchestrating Europe: The Informal Politics of the European Union 1973-95, Fontana Press, London, 1995. See also T. CHRISTIANSEN, S. PIATTONI (eds), Informal Governance in the European Union, Edward Elgar, Cheltenham, 2003.

5. W. WALLACE, op.cit., pp.54-55.

6. W. KAISER, B. LEUCHT, M. GEHLER (eds), Transnational Networks in Regional Integration: Governing Europe 1945-83, Palgrave Macmillan, Basingstoke, 2010; M. GEHLER, Von den Nouvelles Equipes Internationales zur Europäischen Volkspartei: Grenzen und Möglichkeiten transnationaler Parteienkooperation nach dem Zweiten Weltkrieg bis zum Ende des Kalten Kriegs in Europa, in: Mitteilungsblatt des Instituts für soziale Bewegungen, 2(2011), pp.7-37; M. GEHLER, M. GONSCHOR, H. MEYER, J. SCHÖNNER (eds), Mitgestalter Europas: Transnationalismus und Parteiennetzwerke europäischer Christdemokraten und Konservativer in historischer Erfahrung, Konrad-Adenauer-Stiftung, Sankt Augustin, 2013. See also W. KAISER, P. STARIE (eds), Transnational European Union: Towards a Common Political Space, Routledge, London, 2005. 
There is an extensive literature on the 1996-97 IGC and the ToA. ${ }^{7}$ It is striking that this literature deals primarily with formal aspects and fails to engage with the role of Europarties, including EPP, in the making of this new treaty. More broadly, existing literature on treaty reform in the EU has only rarely addressed the role of Europarties or of the party political dimension more broadly in successive treaty reforms or negotiations. ${ }^{8}$

The study has an exploratory character, through careful within-case analysis. ${ }^{9}$ The empirical, within-case, research and analysis is based on the approach known as 'process-tracing', which attempts to assemble 'bits and pieces of evidence into a pattern', thereby explaining the processes at work by accounting for 'this stream of behaviour'. ${ }^{10}$

The case study summarizes existing secondary sources and presents unique primary evidence drawn from different data sources: documents (official and unofficial

7. E.g., G. EDWARDS, A. PIJPERS (eds), The Politics of European Treaty Reform: The 1996 Intergovernmental Conference and Beyond, Pinter, London, 1997; Y. DEVUYST, Treaty reform in the European Union: the Amsterdam process, in: Journal of European Public Policy, 4(1998), pp. 615-631; B. MCDONAGH, Original Sin in a Brave New World: An account of the negotiation of the Treaty of Amsterdam, Institute of European Affairs, Dublin, 1998; W. WEIDENFELD (ed.), Amsterdam in der Analyse: Strategien für Europa, Bertelsmann, Gütersloh, 1998; T. CHRISTIANSEN, K.E. JØRGENSEN, The Amsterdam Process: A Structurationist Perspective on EU Treaty Reform, in: European Integration Online Papers, 1(1999); D. DINAN, Treaty Change in the European Union: The Amsterdam Experience, in: L. CRAM, D. DINAN, N. NUGENT (eds), Developments in the European Union, Macmillan, Basingstoke, 1999, pp.290-310; A. MORAVCSIK, K. NICOLAÏDIS, Explaining the Treaty of Amsterdam: Interests, Influence, Institutions, in: Journal of Common Market Studies, 1(1999), pp.59-85; K. NEUNREITHER, A. WIENER (eds), European Integration After Amsterdam: Institutional Dynamics and Prospects for Democracy, Oxford University Press, Oxford, 2000; A.-C. SVENSSON, In the Service of the European Union: The Role of the Presidency in Negotiating the Amsterdam Treaty 1995-97, Uppsala University, Department of Government, Uppsala, 2000; J. MONAR, W. WESSELS (eds), The European Union after the Treaty of Amsterdam, Continuum, London, 2001; D. BEACH, The Dynamics of European Integration: Why and when EU institutions matter, Palgrave Macmillan, Basingstoke, 2005; F. LAURSEN (ed.), The Amsterdam Treaty: National Preference Formation, Interstate Bargaining and Outcome, Odense University Press, Odense, 2002; S. VANHOONACKER, The Amsterdam Treaty: Modest Reforms, in: F. LAURSEN (ed.), Designing the European Union: From Paris to Lisbon, Palgrave Macmillan, Basingstoke, 2012, pp.180-195.

8. For rare contributions, see P. BUDDEN, The Making of the Single European Act: the United Kingdom and the European Community: 1979-1986, unpublished thesis presented to the Faculty of Modern History at the University of Oxford, 1994; P. BUDDEN, Observations on the Single European Act and 'relaunch of Europe': a less 'intergovernmental' reading of the 1985 Intergovernmental Conference, in: Journal of European Public Policy, 1(2002), pp.76-97; K.M. JOHANSSON, op.cit., 1999, 2002a, 2002b; S. LIGHTFOOT, Europeanizing Social Democracy? The rise of the Party of European Socialists, Routledge, London, 2005; S. VAN HECKE, op.cit., 2012.

9. E.g., A.L. GEORGE, A. BENNETT, Case Studies and Theory Development in the Social Sciences, MIT Press, Cambridge, Mass., 2005.

10. A.L. GEORGE, T.J. MCKEOWN, Case Studies and Theories of Organizational Decision Making, in: L. SPROULL, V. LARKEY (eds), Advances in Information Processing in Organizations, vol.2, JAI Press, Santa Barbara, 1985, pp.21-58, here p.36. See also A. BENNETT, J.T. CHECKEL (eds), Process Tracing: From Metaphor to Analytic Tool, Cambridge University Press, Cambridge, 2014. 
and mainly relating to EPP summits), correspondence, and elite interviews with officials, special advisers and politicians, among them three Prime Ministers. ${ }^{11}$ The interviewees in principle appeared on record, and none of them specifically requested anonymity. In addition, the study draws on conversations, which are on deep background in the article, and on direct observation at EPP (and EPP group) meetings and EPP congresses over the course of the 1990s (and 2000s). I have attempted as far as possible to corroborate findings by cross checking different sources of information - to make a validity check.

The article proceeds in two steps and substantive sections. The first section presents the case study, outlining the activities and role of the EPP in the process of treaty reform. Then I conclude by summarizing and discussing the main findings.

\section{Case Study}

The Maastricht treaty or Treaty on European Union (TEU) provided that a further IGC should be convened in 1996 to review the treaty, thereby already identifying some specific issues for consideration and possible reforms. ${ }^{12}$ They included, among other things, a review of the two intergovernmental pillars - the second pillar, common foreign and security policy (CFSP), and the third pillar, Justice and Home Affairs (JHA) - and the scope of co-decision, that is, a possible extension of the number of areas in which the EP acts in 'co-decision' with the Council of Ministers, as well as of qualified majority voting (QMV) and of the competences of the Union.

That another IGC should be convened was something the EPP pushed for. ${ }^{13}$ The idea of a treaty commitment to a review conference in 1996 would keep 'alive the

11. Jean-Claude Juncker, Prime Minister of Luxembourg (7 June 2000), Ruud Lubbers, former Prime Minister of the Netherlands (15 June 2000), and Wilfried Martens, former Prime Minister of Belgium and President of the EPP 1990-2014 (30 March 2000). Among the other interviewees are Elmar Brok, MEP, CDU, representative of the EP in the 1995 Reflection Group and the 1996-97 IGC (25 February 1998), Pascal Fontaine, Deputy Secretary-general of the EPP group (24 September 1997), Inigo Méndez de Vigo, MEP, representative of the President of the EP during the 1996-97 IGC (11 May 2000), Brian Murphy, adviser to the Irish Minister for European affairs Gay Mitchell (Fine Gael) (10 October 1997), Nora Owen, Minister of Justice and deputy leader of Fine Gael (9 October 1997), Hans-Gert Pöttering, MEP, CDU, Vice-Chairman of the EPP group, Chairman of the EPP working group 'Preparation for the 1996 Intergovernmental Conference' (25 February 1998), and Klaus Welle, Secretary-general of the EPP 1994-99 (12 March 1995 and 9 January 1997).

12. E.g., S. VANHOONACKER, op.cit., pp.183-184.

13. EPP, Niederschrift vom Treffen der Regierungschefs der EVP, 26.11.1991; EPP, Note en vue de la réunion des Chefs de gouvernement du 26 novembre, 19.11.1991. See also F. LAURSEN, S. VANHOONACKER, R. WESTER, Overview of the Negotiations, in: F. LAURSEN, S. VANHOONACKER (eds), The Intergovernmental Conference on Political Union: Institutional Reforms, New Policies and International Identity of the European Community, Martinus Nijhoff, Dordrecht, 1992, pp.3-24, here p.20; R. DUNPHY, Conservative and Christian Democrat Debates on European Union, in: P. MURRAY, P. RICH (eds), Visions of European Unity, Westview Press, Boulder, 1996, pp.131-157, here p.155; K.M. JOHANSSON, op.cit., 2002a, pp.881-883. 
notion of parallel progress in EMU and in political union...' ${ }^{14}$ Economic and monetary union, EMU, was not for the IGC but was discussed in parallel amid concerns with the convergence criteria, not least price stability, and the independence of the European Central Bank. Helmut Kohl, the German Chancellor, wanted to see the fulfilment of EMU, including the single currency, which must be made irreversible. EMU remained the key priority of Kohl and his European policy. Addressing the Bundestag on 13 December 1991, Kohl

'admitted that he had hoped for more on political union but stressed that EMU, along with the single European market, had unleashed a dynamic process that would reap dividends on political union in $19966^{\prime} .{ }^{15}$

The Christian Democrats were a strong federalist movement behind the Maastricht outcome. On many points the outcome was close to the EPP's demands, and what was achieved on further points 'left open the hope of a breakthrough at the conference to revise Maastricht, pencilled in for 1996'. ${ }^{16}$ The EPP Bureau met to discuss and evaluate the Maastricht outcome. Especially in the second and third pillar areas the treaty did not live up to the expectations of the EPP. There were great achievements but a Union was not yet achieved. This is why the Maastricht outcome met with mixed feelings within the EPP, with its federalist blueprint for a true Union.

So the new treaty had barely been adopted when the preparations for the next IGC were taking off in the EPP. In February 1992 both the EPP Bureau and the EPP Conference (of Party Leaders and Heads of Governments) met to assess Maastricht and to brainstorm about the IGC agenda, the issues and priorities. On the eve of the signing of the TEU, the EPP Bureau met in Brussels on 6 February. Several speakers emphasized the shortcomings of the treaty, particularly in the institutional field. Instead of the pillar structure, the EPP favoured a single institutional framework. The decisions on co-decision, CFSP and social policy were obviously seen by many speakers as half-hearted and unsatisfactory compromises. With attention to the shortcomings of the TEU the EPP, in a resolution,

'reaffirmed its determination to move the continent of Europe forward on the road to federal unity by means of a Constitution founded on the principles of subsidiarity, democracy and solidarity'. ${ }^{17}$

The new treaty reform must combine the goals of enlargement and the deepening of the Union. EPP President (and Belgian premier) Wilfried Martens: 'The EPP is not giving up the idea of a federal Europe and will continue to struggle for its fulfilment before the third millennium'. ${ }^{18}$

14. K. DYSON, K. FEATHERSTONE, The Road to Maastricht: Negotiating Economic and Monetary Union, Oxford University Press, Oxford, 1999, p.442.

15. K. DYSON, K. FEATHERSTONE, op.cit., p.451.

16. T. JANSEN, The European People's Party: Origins and Development, European People's Party, Brussels, 2006, p.112.

17. EPP, Resolution of the EPP Bureau, 06.02.1992. See also EPP Bulletin, 2(1992); Agence Europe, 14.12.1991 and 08.02.1992.

18. Quoted in EPP Bulletin, 2(1992). 
The EPP Bureau met also to prepare the subsequent meeting of the EPP Conference; convened in Brussels on 14 February 1992.19 Among the EPP heads of government present were Kohl, Ruud Lubbers, the Dutch premier, and Martens.

Several party leaders attended the meeting, including José-Maria Aznar from Spain, John Bruton from Ireland, and Jean-Claude Juncker from Luxembourg. On the agenda was an evaluation of Maastricht and the future actions of the EPP with regard to the realization of European union. ${ }^{20}$ Although self-congratulatory and considering Maastricht largely a success, it was emphasized that not all demands were satisfactorily met. Lubbers was among the speakers like Kohl, who particularly mentioned EMU and political union as well as the strengthening of the EP. In the debate there was a special reference to the 1994 European elections, and participants were looking forward to substantial reform in the treaty review due to start in 1996.

In view of this Conference meeting, a note, an evaluation, was prepared on the results of the Maastricht treaty, whether the outcome met the EPP's demands, in which it was concluded 'that the results of the Maastricht Conference owe a great deal to concerted action among the Christian Democrats'. ${ }^{21}$ Perhaps most important, the note stressed with regard to EMU that no member state is 'to be allowed to prevent the others embarking on the final stage - a satisfactory solution...'. The 'opting-out' clause was limited to the UK in a protocol. In the general assessment, with reference to the social and monetary spheres, the scenario was raised that the UK's opt-out might serve as a precedent for an institutional arrangement allowing a member state to exclude itself from a policy without preventing the others from going ahead in a Community framework. The prospect of such a Union with 'variable components' would be subject to closer scrutiny. It was concluded that the 'six EPP heads of government formed a hard core of advocates of federalization'. In sum:

'Maastricht concluded on an agreement of substance, as those attending the EPP summit had hoped. EMU is now an irreversible process which will lead to a single currency. Political union and democratization have made progress, even if further advances will be needed, and will be set in motion in 1996 at the latest. [...] The EPP must take the initiative once again to give substance to the 1996 revision clause. The Christian Democrats must quickly define their positions on the main European issues of the next few years:

- the strengthening of institutions - a precondition for the success of any further enlargements;

- the creation of a European executive;

19. EPP, The Conference of EPP Heads of Government and Parties, Val Duchesse, 14.02.1992. See also EPP Bulletin, 2(1992); Agence Europe, 17/18.02.1992.

20. EPP, Niederschrift der Konferenz der Partei- und Regierungschefs der EVP, 14.02.1992.

21. EPP, Does the Outcome of Maastricht Meet the EPP's Demands?, Note for the Conference of EPP Heads of Government and EPP Party Leaders, 14 February, Brussels, 21.01.1992; EPP, Tragen die Ergebnisse von Maastricht den Forderungen Rechnung?, Aufzeichnung [by Pascal Fontaine of the EPP group secretariat]. Hinweise für die Konferenz der Partei- und Regierungschefs der EVP, 14.02.1992. 
- a reduction of the democratic deficit;

- a European defence identity, to cover the nuclear issue'.

It all amounted to the implementation of a true European union, with the EPP now looking to 1996 and the forthcoming IGC. The EPP reaffirmed its federal agenda, emphasizing the extension of EP co-decision powers and institutional reform. Regarding policy, the EPP emphasized the second pillar (CFSP), calling for common security and defence policies, and the third pillar (JHA) with the extension of common policy in the fields of immigration, asylum and trans-border co-operation against crime. Internal security, part of the third pillar, should be given special priority.

In the interval between Maastricht, which was signed in February 1992 and entered into force in November 1993, and the start of the IGC in Turin in March 1996, the EPP continued to mobilize, exchange ideas and forge links, thereby maintaining a momentum in the process of European integration and treaty reform.

Successive EPP congresses reiterated the demand for a federal European union. In November 1992, the EPP Congress in Athens adopted a new programme. At the December 1993 Congress in Brussels, the EPP adopted its 1994-99 action programme. These programmes pushed for a federalist solution, just like the EPP manifesto for the June 1994 European elections. ${ }^{22}$

After the European elections EPP President Martens was elected Chairman of the EPP parliamentary group. In his pro-federalist speech in September 1994, Martens emphasized that the preparatory work ahead of the 1996 IGC has the highest priority for the EP and that its members will take an active part in 'the discussions on the future shape of Europe'. ${ }^{23}$ This was something German Chancellor Kohl worked for.

Re-elected Chancellor after the general election of October 1994, Kohl presided over the European Council during the German EU presidency the second half of that year. The December 1994 Essen European Council agenda included the IGC due to start in 1996. In their pre-summit meeting in Brussels on 8 December the EPP leaders discussed the IGC agenda and 'decided to have an open exchange of views on the agenda of the EU without the pressure of adopting a position on the forthcoming Council'. ${ }^{24}$ Now there were only three EPP heads of government - in addition to Kohl, Belgium's Jean-Luc Dehaene and Luxembourg's Jacques Santer. ${ }^{25}$ The official minutes reveal that the EPP leaders were concerned about the small number of Christian Democrats in the European Council, but in response to particular concern of the Dutch and Italian parties Dehaene, Kohl and Santer 'promised that the positions taken by their governments in the 1996 IGC would be closely coordinated with the policies

22. EPP Bulletin, April 1994.

23. Wilfried Martens, Deepening and Widening: A Strategy for the European Union, speech in Brussels, 20.09.1994.

24. S. HIX, C. LORD, Political Parties in the European Union, Macmillan, Basingstoke, 1997, p.194.

25. EPP, Einladungsliste EVP-Gipfel, 08.12.1994. Approved by the EP in January 1995, Santer took office as Commission President and was replaced as Prime Minister of Luxembourg by Jean-Claude Juncker. In December 1994, John Bruton, the Fine Gael leader, replaced Albert Reynolds as Ireland's Prime Minister, increasing the number of EPP Prime Ministers to four. 
of the EPP party'. ${ }^{26}$ The positions taken by these governments, notably the German, would also be closely co-ordinated with the EPP parliamentary group.

During the first half of 1995 France held the presidency of the EU, and in June Cannes was the venue for the European Council summit, as well as for the EPP Conference meeting on 25 June. Except for preparing for the subsequent European Council, the 1996 IGC was on the agenda at this EPP pre-summit meeting. In addition to party leaders and heads of government - this time except Kohl who had to stay in Bonn to address the parliament - the Commission President took part at the EPP meeting along with the EPP presidency and leading officials. ${ }^{27}$ The day before an event, sponsored by the bureau of the EPP group, was held on 'Coordinating the Strategy of the Union Institutions' for the 1996 IGC. Commissioners took part. The EPP group discussed its own strategy at a separate meeting.

The French presidency was followed by the Spanish presidency. It was during this period, between June and December 1995, that the Reflection Group met to prepare the agenda and objectives for the IGC, laying down markers for the scale of the agenda of the negotiations. Its conclusions

'set the practical arrangements for the IGC, including the decision that the IGC would finish in June 1997 under the Dutch presidency, in an effort to postpone the conclusion of the IGC until after the expected Labour victory in the upcoming British elections, which were to be held at the latest in May 1997'.28

But no major breakthrough could be expected until after the UK election due for spring 1997.

During the Spanish presidency Madrid was the venue for the EPP summit in November 1995, in the presence of three heads of government: Bruton, Dehaene, Juncker. Wolfgang Schäuble represented Kohl, supposedly absent because he was unwilling to intervene in Spanish electoral politics since he had established a good personal relationship with Félipe González, the leader of the Spanish socialist party and government. Aznar, leader of the Partido Popular and a Vice-President of the EPP, used the occasion for electoral purposes. Among the other party leaders present were François Bayrou and Wolfgang Schüssel. This was in the context of the EPP Congress, which adopted the document or position paper 'Ability to Act, Democracy and Transparency - the European Union on the Road to a United Europe'. It advocated a federal EU and served as the EPP's contribution to the debate on the forthcoming IGC, with a particular emphasis on institutional reform in the EU. The EPP remained focused on institutional reform, to prepare the EU for enlargement, as well as on second and third pillar issues. The IGC must integrate the three pillars into a common framework, applying the Community method. The paper was based on deliberations in the EPP ad hoc working group 'Preparation for the 1996 Intergovernmental Con-

26. S. HIX, C. LORD, op.cit., p.194.

27. Kohl and Martens met prior to this EPP summit. EPP News, 21(1995). See also Agence Europe, 24.06 .1995 .

28. D. BEACH, op.cit., p.116. 
ference', which was set up by the EPP Bureau in 1994. The working group was chaired by Hans-Gert Pöttering, German MEP and Vice-Chairman of the EPP group, assisted by the EPP secretariat, and consisted of representatives of member parties. ${ }^{29}$ They contributed to the draft position paper, which was developed during the course of 1995. But the work started already in 1994. Pöttering worked closely together with the Secretary-general of the EPP, Klaus Welle, also from CDU. ${ }^{30}$ Welle was active and closely associated with the work. ${ }^{31}$ So the forces behind this document included politicians and officials linked to Germany's CDU. In the course of the work, there were consultations with the Chancellor's office in Bonn. The working group met with Kohl's special adviser for EU and foreign affairs Joachim Bitterlich at an early stage and subsequently with the French Minister for Europe, Alain Lamassoure. ${ }^{32}$ Thus, the paper was the product of intensive consultation also at the highest levels of party and government. Yet, the paper constituted a transnational policy contribution by the EPP. There were co-ordination activities with the parliamentary group. The proposals put forward by the EPP working group were co-ordinated with and discussed in a working party on the IGC set up by the EPP group. The IGC and the treaty review had top priority.

Following the statutory changes agreed at its congress in Madrid in November 1995, the EPP undertook some organizational reforms. The EPP set up a Council to be composed of mainly party leaders and Secretary-generals of member parties. At the first meeting of the EPP Council in Brussels on 8 February 1996 the IGC was the 'main subject' and people in attendance included Martens and Elmar Brok, the EP representative in the Reflection Group and IGC, as well as Commission President Santer and Marcelino Oreja, Commission representative in the Reflection Group and IGC group. Bayrou, President of Force Démocrate and Education Minister, was elected President of the EPP Council at its meeting in Dublin in May 1996. ${ }^{33}$ For the EPP this was a way of involving Bayrou, Minister of the French government. The EPP Council met several times in 1996 and during the time of the IGC itself. Moreover, the EPP re-organized at the top, at its highest political level. Since the main task of the pre-meetings - at least for heads of government - is to prepare European Council summits, it is important for those representing governments at this level to be able to communicate in a relatively small and informal setting. Therefore Kohl came to look upon the Conference as an inconvenient body since it not only encompassed people in government. Instead, the EPP Summit or 'mini-summit' was established, restricted to the EPP heads of government, the party leaders in coalition governments, the EPP presidency, and the Commission President - and still with the main

29. Pöttering was later to become Chairman of the EPP group and President of the EP.

30. Welle was later to become Secretary-general of the EPP group and subsequently of the EP, a position he holds at the time of writing.

31. Author interview. See also EPP News, 2(1995).

32. Agence Europe, 11.11.1994.

33. EPP, Activities Report 1996/1997, 1997a, p.10. 
purpose of meeting to prepare the impending EU summit. ${ }^{34}$ This change in the statutes was first applied in December 1995 when the EPP organized a summit in Brussels before the Madrid European Council.

The IGC agenda came into focus, following the publication of the Reflection Group's report. Based upon the report and the Madrid European Council the Italian presidency inherited an emerging IGC agenda. The three main themes were to be an attempt to bring the EU closer to citizens, institutional reform, and creating more effective external policies. The IGC was officially opened at the March 1996 Turin European Council summit.

The EPP continued to mobilize and make efforts to shape the agenda for the IGC and for the EU. At the top the EPP was strengthened when Aznar became Prime Minister as a result of Partido Popular's victory in the general election in Spain in March $1996 .{ }^{35}$ When the IGC officially opened in March 1996 the EPP now brought together the heads of government from Belgium, Germany, Ireland, Italy, Luxembourg, and Spain: Dehaene, Kohl, Bruton, Prodi, Juncker, and Aznar. At first, Romano Prodi was not officially an EPP head of government, but Kohl wanted him involved. In addition, three leaders of EPP member parties who also held senior ministerial posts in the coalition governments of Austria, Finland and France were also involved: Schüssel (Vice-Chancellor and Foreign Minister), Sauli Niinistö (Finance Minister), and Bayrou (Education Minister). Moreover, Commission President Santer was there.

The EPP (Mini-) Summit met three times during 1996 - in June, July and December. Before the Florence European Council in June the EPP organized a minisummit in Brussels on 11 June, in the presence of the following heads of government: Aznar, Bruton, Dehaene, Juncker, Kohl, and Prodi (who was not yet officially an EPP head of government). In addition, Bayrou and Niinistö and Commission President Santer also took part. The main issues on the agenda were the preparation of the EU summit in Florence and the priorities of the Irish presidency. ${ }^{36}$

At Florence the Italian presidency submitted a 'progress report' on the IGC and the conclusions of the European Council stated that the pending Irish presidency was to prepare, for the Dublin European Council in December 1996, a general outline for a draft revision of the treaties intended to 'mark decisive progress' towards completing the IGC by mid-1997, 'seeking balanced solutions to the main political issues raised' ${ }^{37}$ Substantively, the Irish presidency draft should address in particular a number of aims, which 'came closer than previous efforts had done to defining the real agenda of the IGC'. According to McDonagh, 'the list of aims identified at Flo-

34. In addition, the Chancellor continued to invite, from time to time, a small group of trusted people of the EPP and member parties to so-called bungalow/Chancellor talks in Bonn.

35. Partido Popular became a full member in the autumn of 1991. Aznar was a Vice-President of the EPP until June 1997.

36. EPP News, 62(1996).

37. B. MCDONAGH, op.cit., pp.65 and 70. See also A.-C. SVENSSON, op.cit., p.90; D. BEACH, op.cit., p.117. 
rence bears a significant similarity to the contents of the eventual Treaty of Amsterdam'.

The IGC now moved into its next stage - the Irish presidency during the second half of 1996. Along path-dependent lines the Irish presidency, like any EU presidency, inherited a number of agenda items. Seeking solutions to the main political issues raised and to develop consensus, the Irish presidency acted to shape agreement on each topic through a process of 'successive approximations', the emerging agreement wherever possible taking the form of specific treaty language. ${ }^{38}$

The EPP's Irish member party Fine Gael was in government with its leader John Bruton serving as Prime Minister (Taoiseach) and thus also President of the European Council during the second half of $1996 .{ }^{39}$ Notably, at EPP Summit meetings and on other occasions he met with Chancellor Kohl, who, according to Bruton, 'tended to lead the discussions within the EPP'. ${ }^{40}$ Moreover, the deputy leader of Fine Gael, Nora Owen, was Justice Minister and the party also held the post of Minister for European affairs through Gay Mitchell who represented the Irish government in the Reflection Group. All three spoke at the EPP Council meeting at the Dublin Castle in May 1996 and presented reports. ${ }^{41}$ Mitchell presented a document on employment. Owen outlined a report on the fight against drugs. Thus, preparation for the Irish presidency was at the centre of this EPP Council meeting at which the "employment situation in Europe and the problems of drugs were central to the debate', and in preparing for the meeting of heads of government together with the EPP presidency of 11 June. ${ }^{42}$ At the June EPP mini-summit Bruton presented his report and

'set out the priorities for the Irish Council presidency during the second half of 1996, giving special emphasis to the issues of unemployment and the fight against drugs. He also presented a discussion paper containing proposals for including common acts of European citizenship into the European Union treaties'. ${ }^{43}$

Thus, there was a special emphasis on employment and third pillar issues.

A special EPP Summit took place in Luxembourg on 10 July 1996, in the presence of all the then six EPP heads of government - Aznar, Bruton, Dehaene, Juncker, Kohl and Prodi who now was officially an EPP head of government - plus the Austrian Vice-Chancellor Schüssel and the French Education Minister Bayrou and Commission President Santer. Bruton asked for this special EPP Summit, for a detailed discussion of the Irish presidency, and on this occasion they raised the issue of internal

38. B. MCDONAGH, op.cit., p.83.

39. The Irish government was a coalition between Fine Gael, EPP member, and Labour, PES member. Labour and its Ministers likewise availed themselves of party and personal networks through the European party family to which it belonged. K.M. JOHANSSON, op.cit., 1999. Bruton was Prime Minister of Ireland from 1994 to 1997. He later became a Vice-President of the EPP.

40. Personal letter to the author, 14.08.1997.

41. Part of a delegation of political scientists, I visited the Dublin Castle when the EPP Council met there.

42. EPP, op.cit., 1997a, p.10.

43. EPP News, 62(1996). 
security and were determined not to begin with institutional questions but issues closer to the people. ${ }^{44}$ Bruton said that

'one of the central concerns of the Irish presidency was the Europe-wide fight against crime and practical measures to combat unemployment'. ${ }^{45}$

The main priority of this EPP Summit meeting was the preparation of the next, extraordinary, summit of the EU.

At the Dublin 1 European Council in October 1996 there were different views on the scope of the IGC agenda. But there was an emerging consensus on key issues, notably employment and in the JHA area, notes McDonagh:

'These two issues were clearly to the forefront of thinking at the highest political level, no doubt reflecting domestic public concerns. This represented a more genuine political input than the prior identification of specific issues for the meeting would have done' ${ }^{46}$

National delegations were seeking to 'discern potential zones of agreement' ${ }^{47}$

The consensus was reflected in an interim document drafted and presented by the Irish presidency before the December 1996 Dublin 2 European Council, which was another stepping stone on the road to Amsterdam. In the run-up to the Dublin summit the EPP organized meetings in Brussels of its Bureau, Council and Summit. At the EPP Council meeting on 5 December of party leaders and Secretary-generals of member parties two Prime Ministers, Aznar and Bruton, were present as speakers. Aznar spoke about the need for joint efforts to fight organized crime, drug trafficking and above all terrorism, whereas Bruton spoke about the final document of the Irish presidency, including the employment issue. Brok reported on the IGC. The EPP Summit met the same day, in the presence of six heads of government: Aznar, Bruton, Dehaene, Juncker, Kohl, and Prodi. Again, Bayrou, Niinistö and Schüssel were present, just like Santer. On this occasion there was an 'intensive discussion to prepare the EU Summit in Dublin' and 'they also discussed the progress of the IGC' until the Amsterdam summit due in June 1997, and planned a special EPP mini-Summit for March $1997 .{ }^{48}$

At the Dublin 2 European Council in December Bruton discussed 'difficulties' and wanted 'advice' and 'help' from Kohl and others, as revealed by one interviewee. Except for the IGC, EMU dominated the meeting. It was overshadowed by the acrimony especially between France and Germany over the Stability Pact. ${ }^{49}$ Juncker stepped in to mediate. Kohl, who wanted to see the fulfilment of EMU, emphasized budgetary management and discipline; stability policies that subsequently were codified in the Stability and Growth Pact agreed at the Amsterdam European Council in June 1997.

44. Interview Welle.

45. EPP News, 67(1996).

46. B. MCDONAGH, op.cit., p.101.

47. D. BEACH, op.cit., p.118.

48. EPP, op.cit., 1997a, p.8. See also EPP News, 82(1996).

49. B. MCDONAGH, op.cit., p.126; K. DYSON, K. FEATHERSTONE, op.cit., p.776. 
The Dublin 2 European Council adopted the Outline Draft Treaty as well as the Dublin Declaration on Employment (separate from the Draft Outline Treaty). The employment chapter, as pioneered by the Party of European Socialists (PES), was effectively adopted at the Dublin European Council in December 1996, when six months of negotiations still remained. The text subsequently underwent few changes. It is noteworthy that both Britain's conservative Prime Minister John Major and Germany's Chancellor Kohl now seemed to accept a chapter or title on employment in the new treaty.

Operating in different political circles, through different ways of developing consensus and seeking solutions to the main political issues raised, the Irish presidency contributed an interim document on the IGC that, like the consecutive draft treaty of the subsequent Dutch presidency, was designed to capture the 'zone of agreement'. ${ }^{50}$ But the Irish presidency was not able to broker agreement on all issues. Whereas there was, among other things, principled support for an employment chapter or title in the new treaty, there was still substantial disagreement on the manner and scope of communitarization over third pillar (JHA) issues. Despite particular concerns of the Irish delegation in this area, Ireland did not object to the transfer to the first pillar of free movement, asylum and immigration as such and this was in line with the 'strong commitment to the process of European integration'. ${ }^{51}$ An opt-out was possible but seemingly not a veto. The most sensitive issues such as the integration of Schengen into the EU and treaty, the transitional regime for migration and asylum, and the reform of the Council voting system, were left to the Dutch presidency. ${ }^{52}$ On the difficult institutional questions - including size and composition of the Commission - it turned out to be impossible to reach a consensus and it was decided to postpone the debate.

The IGC now entered into its next stage, during the Dutch presidency, which was to manage the IGC in its intensive final phase and towards completion. It inherited the Outline Draft Treaty from the Irish presidency. The outstanding issues discussed and in focus concerned especially JHA, as well as flexibility and the sensitive institutional questions. In its preparations for the Amsterdam endgame, the Dutch presidency too sought to capture the 'zone of agreement'. Delegations submitted new proposals and papers but no major breakthrough in negotiations could be expected before the UK general election due on 1 May. After the Labour Party victory the real negotiations got underway, with the new Blair government indicating that the UK would support moves towards more qualified majority voting (QMV) and co-decision, a reform of the EU institutions, and the incorporation of the Social Charter into the treaty.

To get to know Tony Blair and seek solutions to the outstanding issues in the negotiations a special informal meeting of the European Council took place in No-

50. J. TALLBERG, Leadership and Negotiation in the European Union, Cambridge University Press, Cambridge, 2006, p.220. See also A.-C. SVENSSON, op.cit.; D. BEACH, op.cit.

51. B. MCDONAGH, op.cit., p.169.

52. S. VANHOONACKER, op.cit., p.183. 
ordwijk on 23 May. McDonagh suggests that the Noordwijk European Council helped heads of government 'to familiarize themselves further with the issues and the sensitivities in advance of what was to be their marathon session at Amsterdam' ${ }^{53}$ However, during the meeting, the issue of institutional reform lost steam

'as the sharp cleavage between large and small states showed that it would be difficult to reach agreement without a major push coupled with a willing to compromise' ${ }^{54}$

The EPP, for its part, made concerted efforts to muster a consensus around its priorities, concerning institutions as well as issues, and for a substantial treaty reform. EPP bodies convened and set out their views on the IGC - the Bureau, the Council, and the Summit. At the highest level the EPP Summit convened three times - in March, May and June - with the purpose of trying to work out compromises and reach agreement on the issues in order to strengthen the position in the IGC negotiations.

As noted, the EPP Summit meeting on 5 December 1996 discussed the progress of the IGC until the Amsterdam summit due in June 1997 and planned a special EPP mini-Summit for March 1997. Chancellor Kohl suggested this meeting, which would last for eight hours. ${ }^{55}$ This meeting of the EPP Mini-Summit took place in Brussels on 4 March, in the presence of all six EPP heads of government - Aznar, Bruton, Dehaene, Juncker, Kohl, Prodi - plus Bayrou and Schüssel, Santer and Gil Robles, the EP President, as well as Martens and Welle from the EPP itself. ${ }^{56}$ The IGC was the focus of the meeting. It discussed a discussion paper containing a selection of the main concerns of the former Irish presidency within the framework of the revised EU treaty it proposed and the on-going Dutch presidency. Issues were singled out on which Dublin placed particular importance. It reflected the emerging consensus, for example on the employment chapter, and the lack so far of a clear position, most notably over the voting system in the Council as well as over the number of commissioners in consideration of future enlargements. Seemingly, there was a common position regarding co-decision as the 'standard' legislative procedure involving the EP and the Council where decision by QMV is to become the rule in first pillar areas. QMV is to be introduced 'for all CFSP decisions apart from those involving common action, for instance all decisions relating to military/defence policy'. Decisions by the Council with military or defence implications are to be decided by unanimity. In foreign policy, CFSP, it was proposed to introduce 'constructive abstention' in the case of decisions requiring unanimity. Moreover, it was emphasized that the Union should be accorded a 'legal personality'. Several questions were posed over 'flexibility', according to the document.

53. B. MCDONAGH, op.cit., p.185.

54. D. BEACH, op.cit., p.119.

55. Interview Welle. See also EPP News, 90(1997).

56. EPP, Intergovernmental Conference, Discussion Paper, EPP Mini-Summit, extraordinary meeting, Val Duchesse, 4.3.1997. It was on this occasion that the EPP and its leaders controversially stated 'we hope to have the most intensive cooperation possible with Turkey but Turkish membership of the EU is not possible'. 
This EPP summit meeting 'lasted several hours, excluded even the closest political advisers', and EPP Secretary-general Welle 'was tasked with drafting a proposal for the main elements of the IGC as seen from an EPP perspective, this to be the basis for discussion at the next EPP Summit'. ${ }^{57}$ Then, Aznar would put forward proposals for the EPP position on the reform of the third pillar (internal and judicial policy). It was decided to hold two further summits at which there 'will be intensive debate on the IGC' - in Brussels on 21 May and in Strasbourg on 10 June.

Meanwhile, the EPP Council met in Porto on 24 March, with EU employment policy as one of the 'main topics' and affirming the support for an employment chapter, which was considered to be 'of importance to intensify co-operation, consultation, and the exchange of ideas between Member States in the area of employment policy'. ${ }^{58}$ An employment chapter, as well as the Social Charter, should apply to all member states. At the same time, it was strongly emphasized in this context that the subsidiarity principle should be applied to employment policy, meaning, inter alia, that the main responsibility for employment policy should remain a national and a regional one.

In April, Aznar, Martens and Juncker (accompanied by their spouses) met informally in the national park of Doñana, Andalucia, Spain, with the Spanish Minister of Economy and Finance Minister and Deputy Prime Minister Rodrigo Rato also taking part. Martens, when interviewed, said there was a two hours 'informal' discussion on institutional reform at this meeting, and that Aznar was 'ready' to agree on substantial institutional reform.

To discuss the IGC, ahead of the special Noordwijk European Council meeting two days later, a 'restricted' summit of the EPP was held in Brussels on 21 May, in the presence of all six EPP heads of government: Aznar, Bruton, Dehaene, Juncker, Kohl, and Prodi. ${ }^{59}$ Present were also Niinistö and Schüssel, along with Gil-Robles, Santer, and Martens and Welle of the EPP. On the basis of the 'discussion paper' prepared by EPP Secretary-general Welle the EPP summit focused mainly on institutional questions and second and third pillar issues. According to the EPP, there 'was a consensus on almost all matters which were discussed'.

The EPP claimed that during its May summit 'a sturdy and detailed consensus emerged among the heads of State and government'. However, there was not a complete consensus. To agree on common positions among the EPP heads of government who would be present in Amsterdam, the EPP organized yet another summit to further discuss 'some of the unresolved areas, in which the EPP is keen to take the lead at European level' ${ }^{60}$ Notably, one of these areas concerned the Stability Pact. This extraordinary, restricted and preparatory EPP summit meeting was held on 10 June

57. EPP, op.cit., 1997a, p.34.

58. EPP, op.cit., 1997a, pp.38-39.

59. Agence Europe, 22.5.1997.

60. EPP, op.cit., 1997a, p.36. See also EPP, Extraordinary EPP Summit in Brussels; EPP News, 102(1997) and 107(1997). 
in Strasbourg, in the presence of all the EPP heads of government except Aznar. ${ }^{61}$ Again, Niinistö and Schüssel, Gil-Robles, and Santer were also present, just like Martens and Welle.

The EPP also organized a Council meeting in Brussels on 5 June, at which Juncker spoke and especially about the main objectives of the forthcoming Luxembourg presidency, notably enlargement, whereas Brok, Martens and Santer were the main speakers on the IGC and the upcoming Amsterdam summit. ${ }^{62}$

As the IGC unfolded and with a view to the endgame in Amsterdam, the EPP also organized contacts and meetings of personal aides to the Prime Ministers as well as of party leaders holding other positions in respective governments (in Austria, Finland as well as France before the change of government in early June). This was similar to the 'sub-committee' of the then EPP Conference of party leaders and heads of government during the Maastricht process. ${ }^{63}$ The meetings became a way to cultivate personal trust, to exchange views, not least in order to avoid unpleasant surprises, and to broaden the knowledge of other countries and their domestic politics.

These aides or advisers met as a group of Sherpas. The group also included representatives of the Presidents of the Commission and of the EP, respectively. The Sherpas included the following advisers to Prime Ministers: Joachim Bitterlich (D), Sean Donlon (IRL), Ramon Gil Casares (E), Martine Schommer (L), Johan Swinnen (B), and Armando Varricchio (I). The representative of Commission President Santer was his chef de cabinet, Jim Cloos, and of EP President Gil-Robles the Spanish MEP Inigo Méndez de Vigo. The three party leaders in coalition governments - Bayrou, Niniistö and Schüssel - were also involved, and so was German MEP Brok. In an author interview Brok said that preparations had been made since the autumn of 1996.

Their main task was to strengthen co-ordination and sound out the common ground between the governments, and first and foremost to prepare the EPP Summit meetings. At a critical phase of the treaty negotiations the group of EPP Sherpas met twice, in May and June, to prepare the EPP Summit meetings. However, as noted, the Prime Minister's closest political advisers were excluded from the EPP Summit meeting on 4 March.

So the representative of Chancellor Kohl was his EU and foreign affairs advisor Joachim Bitterlich, who was involved in the 1991 IGCs as Kohl's adviser. Bitterlich was in charge of all foreign and security policy in the Chancellor's office, where the central issues of European policy were decided. According to informants, Bitterlich tended to dominate the group of Sherpas and was listened to with more attention. After all, he was a close and trusted adviser to the Chancellor of Germany.

The EPP Secretary-general, from CDU, had an important role in the network and not least in keeping contact with the capitals, notably Bonn. He co-ordinated with

61. Aznar stayed in Madrid for the state-of-the-nation debate. He was replaced at the EPP summit by the Spanish Foreign Minister, Abel Matutes. Agence Europe, 12.06.1997.

62. EPP, op.cit., 1997a, p.40.

63. T. JANSEN, op.cit., p.110. See also K.M. JOHANSSON, op.cit., 2002a, pp.879-880. 
national representatives of Prime Ministers, like Bitterlich, and had the support of Kohl in the EPP. This was necessary also in order to change the EPP itself. To this end, there were the meetings in Bonn with Kohl, Juncker, and others.

As we have seen, there was a broad but not a complete consensus. But it is not clear to what extent there actually was a common, co-ordinated, EPP position, as inquired into in interviews and conversations. ${ }^{64}$ The talk about consensus and common position cannot conceal a dissonance at the heart of the EPP. Except for its relative numerical weakness in the European Council, the position of the EPP was also weakened as its national parties and leaders, including the heads of government, were more or less ideologically divided. ${ }^{65}$ At the time of the Amsterdam summit in June 1997, traditional Christian Democrats led only the Belgian, German, and Luxembourg governments. Nevertheless, the EPP reached a common position on many of the issues and was able to influence the agenda during the IGC, directly or indirectly.

\section{Conclusion}

This article has examined mobilizing activities in the EPP and its networks, in its efforts to play a role in the negotiations leading to the adoption of the Treaty of Amsterdam in 1997. The article shows the attempts at influence of the EPP in shaping the EU in its constitutional and institutional foundations. Moreover, the article yields interesting observations about the nature and functioning of this Europarty.

During the period between the Maastricht European Council in December 1991 and the Amsterdam European Council in June 1997, which adopted the ToA, there were several instances of party mobilization of the heads of government. Whereas the IGC by definition was 'intergovernmental' and mainly conducted through intergovernmental negotiations, the party networks continued to mobilize over the issues on the agenda for the IGC. Before and during the course of the IGC there was significant activity in the EPP and its networks. Throughout this period, the EPP organized meetings of its different bodies, and a working group devoted to the IGC, to work out compromises between the member parties. Links were also close with MEPs as well as commissioners from EPP member parties. Moreover, the EPP had close connections with several of the presidencies before and during the IGC, and was involved with setting its agenda and shaping its outcome.

64. Author interviews with Brok, Juncker, Martens, Méndez de Vigo, Pöttering, and Welle. See also Wilfried Martens, Speech in Lisbon, 30.05.1997; W. MARTENS, Europe: I Struggle, I Overcome, Springer, Dordrecht, 2008, pp.137-138.

65. See also S. VAN HECKE, Christian Democratic Parties and Europeanisation, in: S. VAN HECKE, E. GERARD (eds), Christian Democratic Parties in Europe since the End of the Cold War, Leuven University Press, Leuven, 2004, pp.43-54, here p.50; J. TALLBERG, K.M. JOHANSSON, Party Politics in the European Council, in: Journal of European Public Policy, 8(2008), pp.1222-1242. 
At the top, the EPP Council and especially the EPP Summit brought together political leaders who were decisive for the finalization and acceptance of a new treaty. EPP heads of government met in the EPP Summit and their closest European advisers met as a group of Sherpas. The main purpose was to strengthen co-ordination and sound out common ground between the governments; to seek to hammer out compromises and a common line and to capture the 'zone of agreement'.

At this the highest political level, it has proved useful for heads of government to get together before European Council summits, not least during IGCs and generally for EU presidencies, such as the Irish presidency. The Prime Minister and other Ministers of the Irish government made conscious efforts to use the party networks through different ways of developing consensus and seeking solutions to the main political issues raised, thereby making it possible for the IGC negotiations to advance toward conclusion. The ultimate aim was to ensure there was agreement on the new treaty.

We are dealing here with different levels of decision-making. At the political level the highest level is the European Council. It is here that the final deals are made. Alongside the intergovernmental or inter-state level and structures there is the transnational element of, for example, party networks involving party elites; national and transnational forces mobilized for the joint cause.

So there is compelling evidence for the role and vigour of the transnational party structures in and around the processes of European integration and treaty reform, beyond the state-centrism present in much of the writings on these processes. Yet, it is not easy to isolate the 'intergovernmental' and the 'transnational' from each other. There is the interplay but also tension between diplomacy, for the 'national interest', and politics, where national political leaders are also party politicians.

Again, it is remarkable that accounts of the 1996-97 IGC and the ToA so far have failed to observe the transnational party-political dimension and structures, which proved useful in the search for consensus and convergence of preferences over the new treaty. Ameliorating this situation, this article suggests a need to take Europarties seriously. They merit greater attention. The article opens up for a systematic study of variation in Europarty mobilization and influence within and across cases and time. The findings carry implications for research on the transnationalization of politics, in particular transnational party and political elite networks, and the EU and its evolution, through its constitutionalization. 